\title{
Influence of Biochar on the Moisture of Dark Brown Soil and Yield of Maize in Northern China
}

\author{
Wenlong Lu, Chunli Kang, Yixue Wang and Zhonglei Xie ${ }^{*}$ \\ College of Environment and Resources, Jilin University, Changchun, Jilin, 130012, P.R. China \\ *For correspondence: xiezhonglei1970@126.com
}

\begin{abstract}
The application of biochar has been shown to increase crop yields on acidic and low activity soils in the tropics but fewer positive yield responses have been reported for soils of Northern China. In field conditions, the application of biochar can raise the crop yields in dark brown soil of Northern China. This study tested the influence of biochar on the moisture of dark brown soil and the yield of two consecutive maize crops. The readily available water (RAW) content (volumetric water available between $-10 \mathrm{kPa}$ and $-100 \mathrm{kPa}$ ) has been re shown to be increased significantly. The bulk density (BD) has been decreased, but moisture uptake hasn't been affected consistently. Following very high stover application rates, the grain yield has been increased by $5 \%$ to $12 \%$ because of the application of biochar in 2013 and 2014, which was presumably because biochar mitigated adverse effects of allelochemicals released from the decomposing maize residue. These results indicate that biochar in combination with crop residue can improve the characteristics of soil moisture and the yield of maize. (C) 2015 Friends Science Publishers
\end{abstract}

Keywords: Biochar; Dark brown soil; Moisture; Bulk density; Maize yield

\section{Introduction}

It has been highly discussed that biochar is a potential amendment to sequester carbon and improve the quality of soil. The application of biochar to the soils has been shown to reduce nutrient leaching and have positive effects on soil physical, chemical and microbiological properties (Laird et al., 2010; Parvage et al., 2012; Basso et al., 2013), which may act in synergy and lead to improved crop performance. However, soil responses to biochar application are strongly affected by the chemical and physical characters and the site-specific soil-biochar interactions. Therefore, predicting the exact effect of particular biochar on soil physicochemical properties and crop yield can pose a challenge (Biederman and Harpole, 2013).

The high internal porosity of biochar produces a soil conditioning agent which can reduce the bulk density, influence the pore size distribution and potentially affect water percolation rates (Bell and Worrall, 2011). It has been indicated by a lot of reports that a positive soil water effect with the application of biochar is due to its high porosity and surface area. It has been demonstrated by Glaser $e t$ al. (2002) that an $18 \%$ increase in the soils amended by biochar is relative to adjacent soils, while a $29 \%$ to $84 \%$ increase has been reported by Basso et al. (2013). During a prolonged drought, the barley yield increased by $10 \%$ in a Chernozem amended by biochar, which resulted from the increase of available water (Karer et al., 2013).
The degree of uncertainty together with characterizing behaviour of biochars in soils also has relation to differences in environment and soil type under, which studies have been carried out. The application of biochar shows the favorable effects on soil quality and productivity of crops in the tropical soils which is highly weathered and with poor nutrients. It has been showed in these studies that the application of biochar had positive influences on both soil characteristics and crop performance, which is partly due to the reduced Altoxicity in the rhizosphere (Glaser et al., 2002). These findings may have no relation with other climatic regions (Glaser et al., 2002; Lehmann et al., 2006; Lehmann, 2007; Atkinson et al., 2010). The restricted filed studies have showed that the addition of biochar to temperate region soils leads to small and transient changes in the agroecosystems with a sufficiently high native soil fertility (Jones et al., 2012). That is to say, the application of biochar to soils in the temperate regions might produce no or limited constrains (Guerena et al., 2013; Karer et al., 2013).

While controlled experiments under the conditions of laboratory and greenhouse offer valuable findings, there was little research being done to address the influence of biochar additions on the soils of northern china in the conditions of field production. Our aim was to quantify the effects of the application of biochar in selected soil moisture characteristics within the Liao River Yuan, uptake and yield of maize over a period of two years. 


\section{Materials and Methods}

\section{Experimental Sites and Biochar}

Experimental sites for the Baoan of Liao River Yuan $\left(42^{\circ} 56^{\prime} 32^{\prime \prime} \mathrm{N}, 125^{\circ} 25^{\prime} 42^{\prime \prime} \mathrm{E}\right)$, Jilin Province (China). This site was farmed in maize-vegetable rotation for the last 5 years. Urea and synthetic fertilizer were two commonly used fertilizers in this area. The soil was air-dried and ground to pass through a $2 \mathrm{~mm}$ sieve and thoroughly homogenized. Soil $\mathrm{pH}$ was determined in a 1:2.5 soil to water suspension (Wang et al., 2013). Total organic carbon (TOC) was measured using an oxidation method with potassium dichromate (Sciubba et al., 2012). Total N (TN) content of the soil samples was determined using an automatic azotometer (KDN-102F, Qianjian Ltd., Shanghai) (Bai et al., 2010). $\mathrm{NO}_{3}^{-}-\mathrm{N}$ and $\mathrm{NH}_{4}{ }^{+}-\mathrm{N}$ contents in the soil were analyzed using spectrophotometric methods with phenol disulfonic acid and indophenol blue reagent, respectively (Bai et al., 2010). Total phosphate (TP) content was spectrophotometrically determined using phosphomolybdate blue (Parvage et al., 2012). Bulk density was measured using a $100 \mathrm{~cm}^{3}$ cylinder that was pressed into the soil (Zhang et al., 2010). Particle size analysis was conducted by the hydrometer method (Spokas and Reicosky, 2009). The soil was classified as a silt loam and its properties are presented in Table 1.

Biochar was produced from corn straw, is a carbonrich organic material obtained though slow pyrolysis under anaerobic conditions (Gaunt and Lehmann, 2008). Straw was chosen because it can produce large quantities of biomass with low nutrient (in particular N) and pyrolysis at relatively high temperature provides biochar with high stability and even lesser N. Following charring, the mass yield was recorded and the sample was milled to pass a 2 $\mathrm{mm}$ sieve prior to further analysis. Total $\mathrm{C}, \mathrm{N}, \mathrm{H}$, and $\mathrm{O}$, $\mathrm{pH}$, surface area, ash content, zeta potential, total acidic oxygen containing groups, $\mathrm{NH}_{4}{ }^{+}-\mathrm{N}$ and $\mathrm{NO}_{3}{ }^{-}-\mathrm{N}$ content were characterized as described by Zheng et al. (2013). The properties of the biochar sample are presented in Table 1.

\section{Experimental Design}

The field experiment was initiated in May 2013, the beginning of the sowing period in the region. Biochar was ground and processed through an 80-mesh sieve (Lehmann et al., 2006). The experiment was conducted in randomized complete blocks designed with three replications. Each block was $20 \mathrm{~m}^{2}$ ( $5 \mathrm{~m}$ long $\times 4 \mathrm{~m}$ wide), with plant and row spacing of 0.2 and $0.3 \mathrm{~m}$, respectively (one plant per hole). Maize was sown on 8 May 2013 and 2014, and conventional methods of irrigation and fertilization were used. Conventional fertilization was performed according to $\mathrm{N}$ concentrations used by farmers in the research area $\left(100 \mathrm{~kg} \mathrm{ha}^{-1}\right)$.

Four biochar applications rated, 0, 20, 40 and $80 \mathrm{Mg}$ $\mathrm{ha}^{-1}$ were replicated three times, which provided 12 field plots in the main experiment. Each plot was surrounded by A $1.5 \mathrm{~m}$ buffer strip to prevent potential confounding due to biochar movement by water, wind or tillage. Biochar was applied to the surface in April in 2013 and 2014, respectively. Immediately incorporated utilizing both rotary and moldboard plow tillage. This brought a relatively uniform distribution of biochar to a depth of approximately $30 \mathrm{~cm}$ and incorporated crop residue $\left(6.5 \mathrm{Mg} \mathrm{ha}^{-1}\right)$ from the last year maize crop, but caused a potentially mix surface condition prior to the planting.

\section{In-season Measurements}

At a seeding rate of 79,074 seeds $\mathrm{ha}^{-1}$, Maize ('cultivar Damin 420') was planted on May 8, 2013. Both the resistance to penetration in the root zone $(0$ to $15 \mathrm{~cm})$ and the volumetric soil moisture content ( 0 to $6 \mathrm{~cm})$ were measured through a Penetrologger equipped with Theta moisture sensor (Eijkelkamp Inc., Giesbeek, The Netherlands). The researchers averaged ten measurements after collecting them across each plot. On May 8, 2014, at a seeding rate of 84,980 seeds $\mathrm{ha}^{-1}$, the researchers planted Maize. In the growing season of 2013 and 2014, the surface volumetric moisture content was collected and measured by a Theta moisture sensor every day from June 11 to July 3 .

\section{The Retention and Bulk Density of Soil Water}

The bulk density of surface soil was decided by undisturbed soil cores collected in July 2013. By metal rings with a inner diameter of $7.5 \mathrm{~cm}$ and a height of $8.5 \mathrm{~cm}$, five samples were got in each plot (Grossman and Reinsch, 2002). While the water retention of soil was decided by the undisturbed surface soil samples which were collected after the harvest season in 2013. By metal rings $(5 \mathrm{~cm} * 3.8 \mathrm{~cm})$ three samples of soil were collected in each lot. The pressure platemthod (Dane and Hopmans, 2002) with a Pressure Plate Extractor (Soil Moisture Equipment Corp., Santa Barbara, USA) determined the water retained at $-10,-33$, and $-100 \mathrm{kPa}$ matric potential. With $0.001 \mathrm{M} \mathrm{CaCl}_{2}$ for $24 \mathrm{~h}$ at $20^{\circ} \mathrm{C}$ the intact cylinders of soil which were held in metal rings were firstly saturated from the bottom up, at the same time, the pressure has gone up to -10 and then $-33 \mathrm{kPa}$. Water which was retained at $-100 \mathrm{kPa}$ was determined by soil put in rubber rings ( $3 \mathrm{~cm}$ diameter by $1 \mathrm{~cm}$ height) and then saturated from the bottom with $0.001 \mathrm{M} \mathrm{CaCl}_{2}$ at $20^{\circ} \mathrm{C}$. The content of readily available water (RAW) in each sample was decided through calculating the difference in volumetric water content held at -10 and $-100 \mathrm{kPa}$ (Fassman and Simcock, 2012).

\section{Harvest of Crops and Measurements of Yield}

In mid-October, the plants reached physiological maturity by hand-harvesting ears from $3 \mathrm{~m}$ of the middle four rows in 
Table 1: Chemical and physical characteristics of the soil and biochar

\begin{tabular}{|c|c|c|c|}
\hline Soil & & Biochar & \\
\hline$\overline{\mathrm{pH}}$ & 5.56 & Yield/\% & 32.8 \\
\hline $\mathrm{TOC} / \mathrm{g} \mathrm{kg}^{-1}$ & 16.8 & $\mathrm{pH}$ & 9.58 \\
\hline $\mathrm{TN} / \mathrm{g} \mathrm{kg}^{-1}$ & 1.52 & $\mathrm{C} / \%$ & 71.3 \\
\hline $\mathrm{NH}_{4}^{+}-\mathrm{N} / \mathrm{mg} \mathrm{kg}^{-1}$ & 65.3 & $\mathrm{H} / \%$ & 3.13 \\
\hline $\mathrm{NO}_{3}^{-}-\mathrm{N} / \mathrm{mg} \mathrm{kg}^{-1}$ & $\mathrm{NA}^{\mathrm{a}}$ & $\mathrm{N} / \%$ & 0.44 \\
\hline $\mathrm{TP} / \mathrm{g} \mathrm{kg}^{-1}$ & 1.06 & $\mathrm{O} / \%$ & 22.8 \\
\hline Bulk density $/ \mathrm{g} \mathrm{cm}^{-3}$ & 1.25 & $\mathrm{NH}_{4}^{+}-\mathrm{N} / \mathrm{mg} \mathrm{kg}^{-1}$ & 16.7 \\
\hline Sand $/ \%$ & 28.1 & $\mathrm{NO}_{3}^{-}-\mathrm{N} / \mathrm{mg} \mathrm{kg}^{-1}$ & 3.21 \\
\hline Silt/ \% & 55.4 & $\mathrm{Ash} / \%$ & 10.0 \\
\hline Clay/ \% & 14.2 & Zeta potential / mV & -43.84 \\
\hline $\mathrm{CEC}^{\mathrm{b}} / \mathrm{cmol}(-) \mathrm{kg}^{-1}$ & 13.7 & $\mathrm{CEC} / \mathrm{cmol}(-) \mathrm{kg}^{-1}$ & 12.2 \\
\hline $\mathrm{WHC} \% \%$ & 31.3 & $\mathrm{WHC} / \%$ & 94.9 \\
\hline \multirow[t]{2}{*}{ Moisture content/\% } & 2.15 & Acid functional group $/ \mathrm{mmol} \mathrm{g}^{-1}$ & 1.21 \\
\hline & & Surface area/ $\mathrm{g} \mathrm{m}^{-2}$ & 2.76 \\
\hline
\end{tabular}

(a) NA: Below the detection limit; (b) CEC: cation exchange capacity, $\mathrm{cmol}(-) \mathrm{kg}^{-1}$; (c) WHC: water holding capacity, \%

each plot before the maize grain yields were estimated. Through harvesting dropped in the center $1.0 \mathrm{~m}$ of the middle two rows of each plot, yields of above-ground biomass were estimated, dried at $60^{\circ} \mathrm{C}$ and then weighed.

\section{Statistical Analysis}

All the analyses of statistics were completed by SAS 9.1 for Windows (SAS Institute). In order to find the statistical differences between the biochar levels, a generalized linear mode (Proc GLM) was used, $\mathrm{P} \leq 0.05$. The relation between variables were obtained by regression procedure (Proc REG), $\mathrm{P} \leq 0.05$.

\section{Results}

\section{Physical Characteristics of Soil}

The volumetric water content in $3 \mathrm{~cm}$ of surface soil in both of the years was increased obviously because of the application of biochar $(\mathrm{P}<0.001)$ (Figs. 1 and 2). In July 2013, when the average volumetric water content was measured, it increased sharply $\left(r^{2}=0.80\right)$ from $24.4 \%$ to $34.3 \%$, with the rise of application rate of biochar from 0 to $80 \mathrm{Mg} \mathrm{ha}^{-1}$ (Fig. 1). In the growing season of 2013 and 2014, the volumetric moisture content was observed every day in a period of two weeks from June 21 to July 3 (Fig. 2). The soil moisture content in the plots amended by biochar was consistently higher and so was the difference between the control plots and the plots amended with biochar during the whole period of monitoring. On average, the volumetric soil water content in the $0-3 \mathrm{~cm}$ layer was increased by 14 to $39 \%$ for the 20 and $80 \mathrm{Mg} \mathrm{ha}^{-1}$ biochar application rate, respectively. In 2013 and 2014, the researchers measured the indicators of soil compaction, soil penetration resistance and bulk density respectively. The average penetration resistance for all plots amended by biochar in $0-15 \mathrm{~cm}$ depth ranged from 1.30 to $1.44 \mathrm{MPa}$, which had no significant difference from that of the control plots with an average of

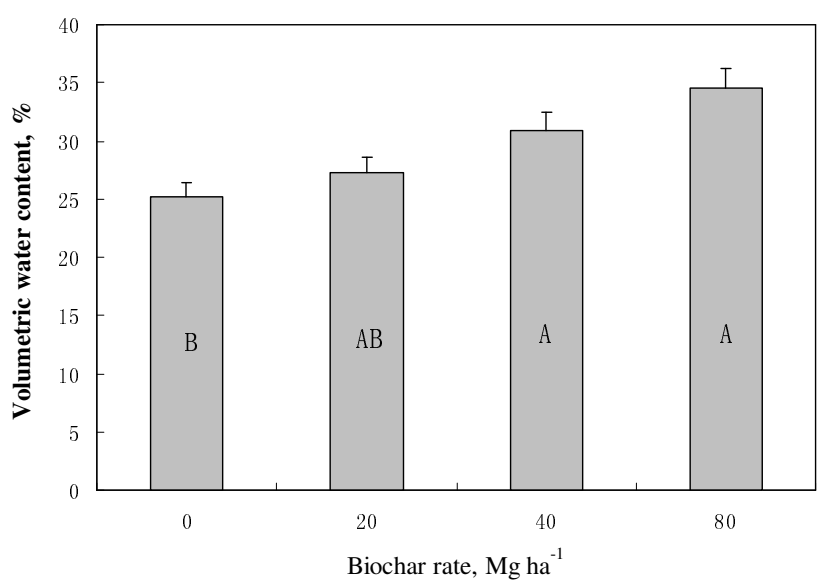

Fig. 1: Differences in volumetric water content (surface 0$3 \mathrm{~cm}$ soil) as affected by biochar applications (One time measurement was made in July, 2013)

of $1.33 \mathrm{MPa}$. However, the Bulk density measurements showed that the application of biochar had a huge impact on the soil compaction (Fig. 3). On average, the bulk density was reduced by the application of biochar from about $1.65 \mathrm{~g}$ $\mathrm{cm}^{-3}$ on control plots to $1.50 \mathrm{~g} \mathrm{~cm}^{-3}$ on plots applied with 80 $\mathrm{Mg}$ biochar $\mathrm{ha}^{-1}$. Biochar accounted for $61 \%$ of variability in bulk density values (Fig. 3). Although the soil bulk density was reduced sharply by increasing the application of biochar, there was no evidence of consistent impact on infiltration or surface runoff rates (Fig. 4). The characteristics of water retention measured in samples which were obtained two years after the application of biochar were shown in Fig. 5. The volume of water retained at a saturation point showed no difference when observed between treatments. Volumetric water content ranged from $0.50 \mathrm{~cm}^{3}$ water per $\mathrm{cm}^{3}$ soil for plots amended with $20 \mathrm{Mg} \mathrm{ha}^{-1}$ biochar to $0.51 \mathrm{~cm}^{3}$ water per $\mathrm{cm}^{3}$ soil for plots amended with $80 \mathrm{Mg} \mathrm{ha}^{-1}$ biochar and was not different from control plots $\left(0.51 \mathrm{~cm}^{3} \mathrm{~cm}^{-3}\right)$. However, the water transportation and retention was influenced a lot by the relative abundance of macro- and micropores in a 
Table 2: The changes of maize single grain weight, 1000 grain weight and yield at different biochar treatment

\begin{tabular}{lllll}
\hline Treatment & Biochar contents $\left(\mathrm{Mg} \mathrm{ha}^{-1}\right)$ & Single grain weight $(\mathrm{g})$ & 1000 grain weight $(\mathrm{g})$ & Yield $\left(\mathrm{kg} \mathrm{ha}{ }^{-1}\right)$ \\
\hline 2013 & 0 & $158.42 \pm 14.75 \mathrm{bc}$ & $288.96 \pm 4.04 \mathrm{bcd}$ & $9931.98 \pm 11.68 \mathrm{c}$ \\
& 20 & $167.88 \pm 14.53 \mathrm{ab}$ & $292.31 \pm 2.42 \mathrm{bcd}$ & $10072.80 \pm 69.35 \mathrm{~d}$ \\
& 40 & $169.22 \pm 3.98 \mathrm{abc}$ & $295.32 \pm 1.79 \mathrm{abc}$ & $10153.29 \pm 42.53 \mathrm{~cd}$ \\
& 80 & $170.81 \pm 9.28 \mathrm{ab}$ & $296.76 \pm 4.51 \mathrm{ab}$ & $10248.73 \pm 27.59 \mathrm{ab}$ \\
& 0 & $160.33 \pm 16.23 \mathrm{abc}$ & $287.36 \pm 8.92 \mathrm{~cd}$ & $9948.52 \pm 22.15 \mathrm{~d}$ \\
& 20 & $165.92 \pm 15.28 \mathrm{ab}$ & $291.31 \pm 6.43 \mathrm{~cd}$ & $10090.32 \pm 45.27 \mathrm{bcd}$ \\
& 40 & $168.84 \pm 4.95 \mathrm{bcd}$ & $292.83 \pm 4.04 \mathrm{bcd}$ & $10530.67 \pm 62.07 \mathrm{c}$ \\
& 80 & $171.47 \pm 6.10 \mathrm{ab}$ & $298.10 \pm 4.65 \mathrm{ab}$ & $10788.15 \pm 97.25 \mathrm{a}$ \\
\hline
\end{tabular}

(a) Average \pm standard deviation $(\mathrm{n}=4)$; (b) The different letters indicate the significant difference $(\mathrm{P}<0.05)$

representative volume but not in the total pore volume. At matric tension of $-10 \mathrm{kPa}$ more water was reserved by soil amended with 40 (11\% increase, $\mathrm{P}<0.1)$, and $80(14 \%$ increase, $\mathrm{P}<0.05) \mathrm{Mg} \mathrm{ha}^{-1}$ biochar compared to no-biochar control soils. At matric potential of $-33 \mathrm{kPa}$ more water was reserved by soil amended with $80 \mathrm{Mg} \mathrm{ha}^{-1}$ biochar compared to control (14\% increase). There was no obvious difference in volumetric water content between biochar treatments being found at matric potential of $-100 \mathrm{kPa}$. Compared with no-biochar control soils, soil amended with biochar showed obviously greater water retained between -10 and $-100 \mathrm{kPa}$ tension) (Fig. 6). Values of RAW of each treatment were $0.04,0.07,0.05$, and $0.08 \mathrm{~cm}^{3}$ of water per $\mathrm{cm}^{3}$ of soil for the control plots, 20, 40, and $80 \mathrm{Mg} \mathrm{ha}^{-1}$, respectively.

\section{Single Grain Weight, 1000 Grain Weight and Yield}

The influence of biochar on the yield of maize can be seen from Table 2. Compared with the control group, 1000 grain weight and yield of the single grain weight were all increased, and the amount increased with different treatments ranged from $6 \%-8 \%$, without significant differences. The insignificance of differences among different treatments showed that with the treatment of biochar, there was no obvious influence on the weight of single grain. The 1000 grain weight in the polt experiments with different treatments of biochar showed no significant differences, while the yield difference between the biochar treated group and the control group was obvious $(\mathrm{P}<0.05)$. That is to say, the use of biochar application can increase the yield of maize a lot.

\section{Discussion}

In this study, the soil moisture responses were the same as the previous studies in laboratories and fields (Laird et al., 2010; Karer et al., 2013). At the same time, it was found that biochar was helpful to raise the crop yields in the periods of moisture stress. Besides, biochar is also useful to decrease the bulk density of soil which could imply the increased pore volume in general. A dilution effect caused by the adding of light-weight, low density material to a much more compacted mineral soil may partly result in the decreases

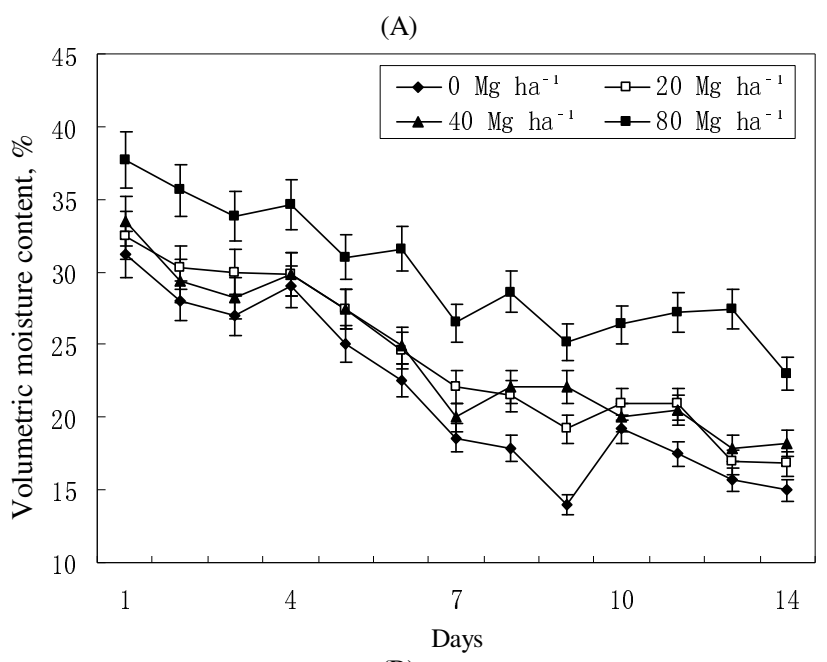

(B)

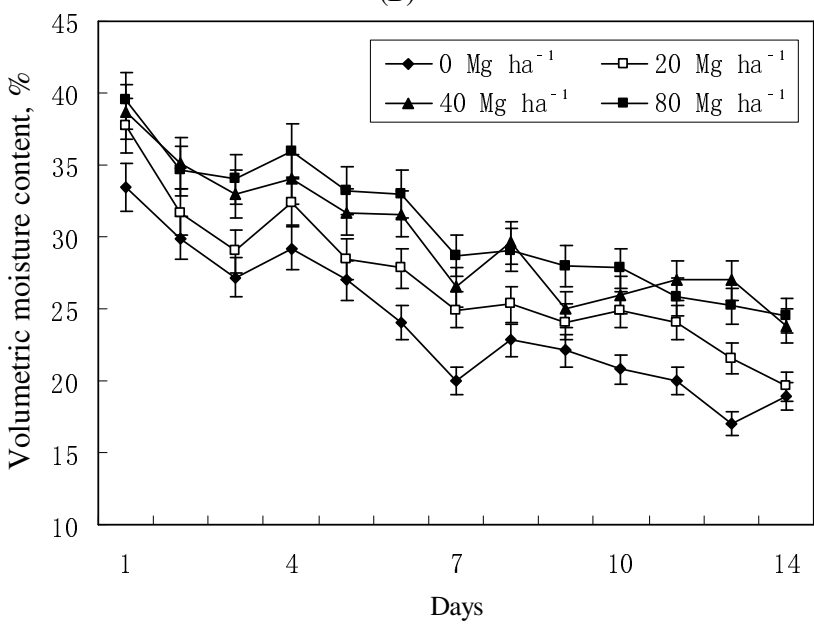

Fig. 2: Temporal variability of volumetric water content in the $0-3 \mathrm{~cm}$ surface soil layer as affected by biochar application rate. Moisture measurements were taken daily for the period in 2013(A) and 2014(B)

in the bulk density as biochar was applied. It is reported that particle density of biochar ranged from 1.54 to $2.06 \mathrm{~g}$ $\mathrm{cm}^{-3}$ (Brewer et al., 2009) depending on the type of feedstock and pyrolystic conditions, and it could also explain the decrease of soil bulk density in the plots amended with biochar in our study. 


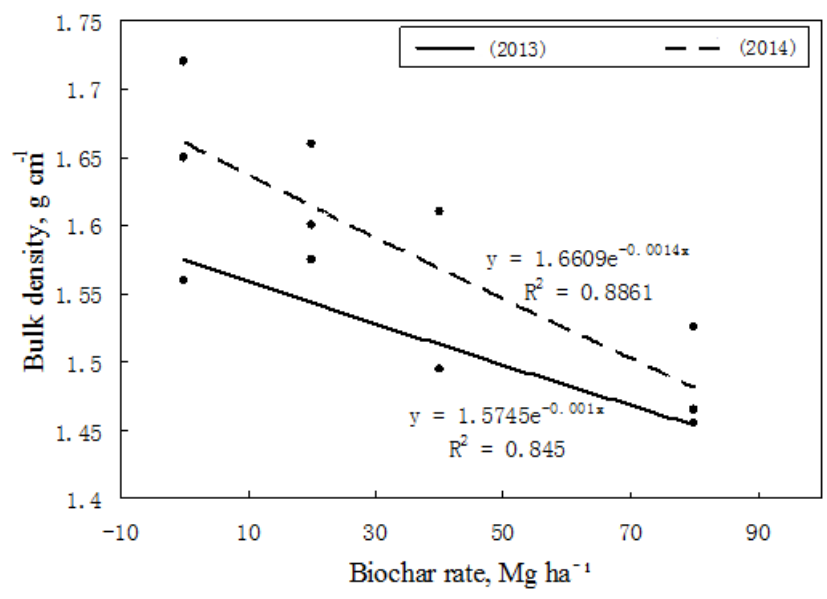

Fig. 3: Soil bulk density as affected by biochar application. Bulk density was measured in 2013 and 2014

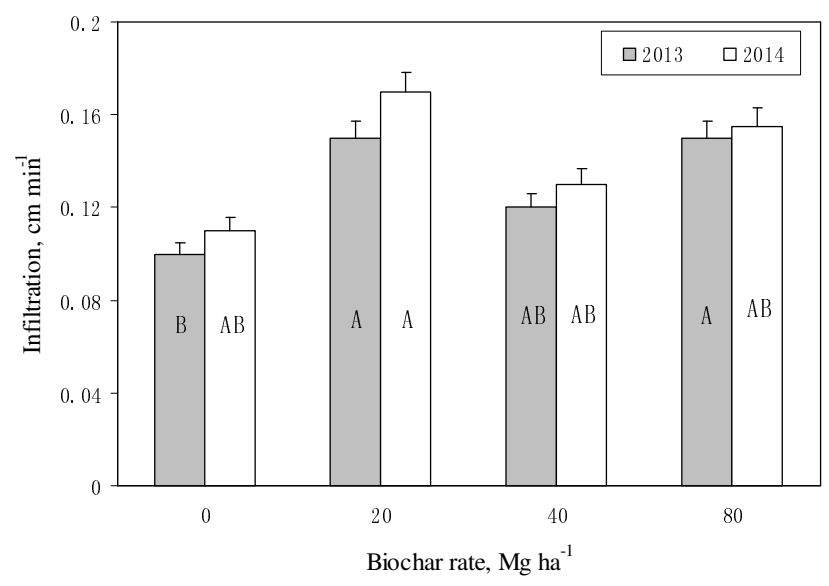

Fig. 4: Impact of biochar on infiltration rate of saturated soil two years after biochar application. Measured in 2013 and 2014. Bars that contain the same letters are not statistically different

The application of biochar led to a significant increase in the grain fields and above ground biomass during after the application in 2013 and 2014. Biochar can not only be a source of nutrients, but also plays the role of slow release fertilizer (Chan and Xu, 2009; Abid et al., 2014). The yield of maize has been increased in the plots amended with biochar (Table 2), which could be partly because of the significantly greater plant supply during the growing season in 2013 and 2014. The precipitation of the total growing season (April through August) that year was 56.7 and 60.3 $\mathrm{cm}$, which was within one standard deviation of the 25 -year average [62.1 $\pm 15.3 \mathrm{~cm}(2014)]$ in this location.

We couldn't see the differences in moisture supply as a key to affect the yield of maize, but there was no clear evidence that moisture stress and crop yields in the external control plots and in adjacent fields were high in general. The risk of $\mathrm{N}$ deficiency was increased by the decomposition of

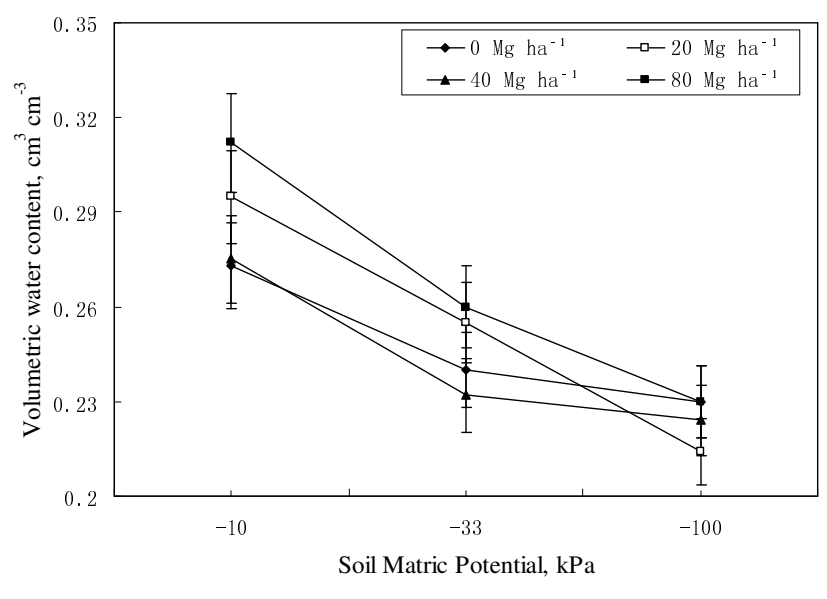

Fig. 5: Water retention curves for soils treated with different rates of biochar

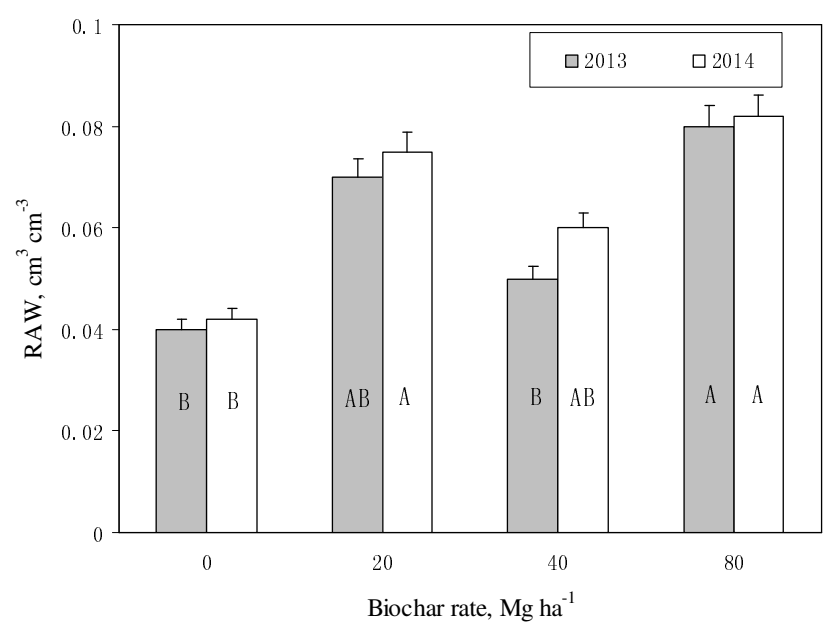

Fig. 6: Differences in readily available water (RAW) content as affected by biochar application rates. Bars that contain the same letters are not statistically different

large amounts of high $\mathrm{C} / \mathrm{N}$ ratio maize residue because of the immobilization of N. In order to decrease the risk, the total amount of the applied fertilizer to the crops in 2014 exceeded the recommended rate by $75 \%$. In the process of crop residue decomposition, phytotoxic compounds can be released, which could prevent the growth and development of maize, it showed that biochar was apparently absorbed and suppressed the negative effects of allelochemicals in aqueous extracts of maize stover (Rogovska et al., 2012), and in previous study it was shown that activated carbon had similar effects to mitigate allelopathy (Inderjit and Callaway, 2003; Kulmatiski and Beard, 2006). It is hard to positively say that phytotoxicity was the reason for the decreased yield of grain in the no-biochar control plots and plots received low rates of biochar. Moreover, there was no evidence to show that the crop in 2013 was restricted by the moisture stress or nutrient deficiencies. 


\section{Conclusion}

The yields of maize grain were promoted by $5 \%$ to $12 \%$ after applying biochar to soils during in 2013 and 2014. The soil bulk density was reduced significantly by the application of biochar, and the surface volumetric water content and RAW went up. In the study on the combination of biochar and crop residue, it would be helpful for us to hypothesize that the allelochemicals were absorbed on the surfaces and then deactivated, which could better guide and benefit the increase of maize harvest in northern China.

\section{Acknowledgements}

Liaohe source technologies and demonstration study area water pollution control issues (No.2012ZX07208-011).

\section{References}

Abid, J., T. Mahmood, A. Khalid, T. Siddique and I. Aziz, 2014. Optimization of pyrolysis yields of paper mulberry (Broussonetia papyrifera) and application of biochar product for the improvement of maize growth. Int. J. Agric. Biol., 16: 929-934

Atkinson, C.J., J.D. Fitzgerald and N.A. Hipps, 2010. Potential mechanisms for achieving agricultural benefits from biochar application to temperate soils: a review. Plant Soil, 337: 1-18

Bai, J.H., Q. Wang, G. Hai-Feng, X. Rong, D. Wei and C. Bao-Shan, 2010. Spatial and temporal distribution patterns of nitrogen in marsh soils from an inland alkaline wetland-a case study of Fulaowenpao wetland, China. Acta Ecol. Sin., 30: 210-215

Basso, A.S., F.E. Miguez, D.A. Laird, R. Horton and M. Westgate, 2013. Assessing potential of biochar for increasing water-holding capacity of sandy soils. GCB Bioenergy 5: 132-143

Bell, M.J. and F. Worrall, 2011. Charcoal addition to soils in NE England: a carbon sink with environmental co-benefits? Sci. Total Environ. 409: 1704-1714

Biederman, L.A. and W.S. Harpole, 2013. Biochar and its effects on plant productivity and nutrient cycling: a meta-analysis. GCB Bioenergy 5 , 202-214

Brewer, C.E., K. Schmidt-Rohr, J.A. Satrio and R.C. Brown, 2009. Characterization of biochar from fast pyrolysis and gasification systems. Environ. Prog. Sustain. Energy, 28: 386-396

Chan, K.Y. and Z. Xu, 2009. Biochar: nutrient properties and their enhancement. In: Biochar for Environmental Management: Science and Technology, pp: 67-84. Lehmann, J. and S. Joseph (eds.). EarthScan, London, UK

Dane, J.H. and J.W. Hopmans, 2002. Soil water retention and storage introduction. In: Methods of Soil Analysis, Vol. 4, pp: 671-720. Dane, J.H. and G.C. Topp (eds.). SSSA, Madison, Wisconsin, USA

Fassman, E. and R. Simcock, 2012. Moisturemeasurements as performance criteria for extensive living roof substrates. J. Environ. Eng. ASCE, 138: 841-851
Gaunt, J. and J. Lehmann, 2008. Energy balance and emissions associated with biochar sequestration and pyrolysis bioenergy production. Environ. Sci. Technol., 42: 4152-4158

Glaser, B., J. Lehmann and W. Zech, 2002. Ameliorating physical and chemical properties of highly weathered soils in the tropics with charcoal-a review. Biol. Fert. Soils, 35: 219-230

Grossman, R.B. and T.G. Reinsch, 2002. Bulk density and linear extensibility. In: Methods of Soil Analysis, Vol, Part 4, pp: 207-210 SSSA, Madison, WI

Guerena, D., J. Lehmann, K. Hanley, A. Enders, C. Hyland and S. Riha, 2013. Nitrogen dynamics following field application of biochar in a temperate North American maize-based production system. Plant Soil, 365: 239-254

Inderjit and R.M. Callaway, 2003. Experimental designs for the study of allelopathy. Plant Soil, 256: 1-11

Jones, D.L., J. Rousk, G. Edwards-Jones, T.H. DeLuca and D.V. Murphy, 2012. Biochar mediated changes in soil quality and plant growth in a three year field trial. Soil Biol. Biochem., 45: 113-124

Karer, J., B. Wimmer, F. Zehetner, S. Kloss and G. Soja, 2013. Biochar application to temperate soils: effects on nutrient uptake and crop yield under field conditions. Agric. Food Sci., 22: 390-403

Kulmatiski, A. and K.H. Beard, 2006. Activated carbon as a restoration tool: potential for control of invasive plants in abandoned agricultural fields. Restor. Ecol., 14: 251-257

Laird, D.A., P. Fleming, D.D. Davis, R. Horton, B. Wang and D.L. Karlen, 2010. Impact of biochar amendments on the quality of a typical Midwestern agricultural soil. Geoderma, 158: 443-449

Lehmann, J., 2007. A handful of carbon. Nature, 447: 143-144

Lehmann, J., J. Gaunt and M. Rondon, 2006. Biochar sequestration in terrestrial ecosystems-a review. Mitigation Adaptation Strategies Global Change, 11: 403-427

Parvage, M., B. Ulén, J. Eriksson, J. Strock and H. Kirchmann, 2012. Phosphorus availability in soils amended with wheat residue char. Biol. Fert. Soils, 49: 245-250

Rogovska, N., D. Laird, R.M. Cruse, S. Trabue and E. Heaton, 2012. Germination tests for assessing biochar quality. J. Environ. Qual., 41: 1014-1022

Sciubba, L., L. Cavani, C. Marzadori, C. Ciavatta, 2012. Effect of biosolids from municipal sewage sludge composted with rice husk on soil functionality. Biol. Fert. Soils, 49: 1-12

Spokas, K. and D. Reicosky, 2009. Impacts of sixteen different biochars on soil greenhouse gas production. Ann. Environ. Sci., 3: 179-193

Wang, Z., H. Zheng, Y. Luo, X. Deng, S. Herbert and B. Xing, 2013. Characterization and influence of biochars on nitrous oxide emission from agricultural soil. Environ. Pollut., 174: 289-296

Zhang, A., L. Cui, G. Pan, L. Li, Q. Hussain, X. Zhang, J. Zheng and D. Crowley, 2010. Effect of biochar amendment on yield and methane and nitrous oxide emissions from a rice paddy from Tai Lake plain, China. Agric. Ecosyst. Environ., 139: 469-475

Zheng, H., Z. Wang, X. Deng, J. Zhao, Y. Luo, J. Novak, S. Herbert and B. Xing, 2013. Characteristics and nutrient values of biochars produced from giant reed at different temperatures. Bioresour. Technol., 130: 463-471

(Received 13 November 2014; Accepted 09 January 2015) 